\title{
PALAVRAS ESCURAS, LUZ DO CANTO: VITORINO NEMÉSIO E O DECADENTISMO-SIMBOLISMO
}

\author{
Leonardo de Barros Sasaki1 ${ }^{1}$
}

\begin{abstract}
RESUMO: Este estudo tem por objetivo contextualizar, dentro da modernidade em sua tendência decadente, a obra poética de Vitorino Nemésio, particularmente sua lírica inicial, que usualmente é associada à nostalgia de sua juventude açoriana. Ao analisarmos os poemas, procuramos responder as perguntas: a) quais as possibilidades de se ler o Modernismo buscando suas raízes na tradição simbolista-decadentista?; e b) de que maneira questões importantes ao fin-de-siècle passaram ao Modernismo e foram exploradas por Nemésio, estabelecendo intersecções e rupturas?
\end{abstract}

PALAVRAS-CHAVE: Simbolismo; Decadentismo; Sermo humilis

ABSTRACT: This article aims to contextualize Vitorino Nemésio's poetic work within the decadent tendency of modernity. We focus on his initial production which is usually associated with his Azorian youth. While reading the poems, we seek to answer the following questions: a) what are the possibilities of reading Modernism by searching its roots in the symbolist-decadent tradition?; and b) how were important topics to the fin-de-siècle assimilated by Modernism and exploited by Nemésio, in establishing intersections and ruptures?

KEYWORDS: Symbolism; Decadent Movement; Sermo humilis

\section{INTRODUÇÃO}

As diversas leituras do Modernismo como objeto histórico não se furtam considerar a herança da movimentação literária finessecular. Ainda que com arcabouço restritivo (BERARDINELLI, 2007, pp. 17-41), Hugo Friedrich (1978) assentava a lírica moderna em três franceses: Baudelaire, Rimbaud e Mallarmé. C.M. Bowra (1943), atendo-se ao que chamou "the heritage of symbolism", parte da triangulação Baudelaire-Verlaine-Mallarmé, para ensaios individuais de poetas como Rilke, Valéry, Yeats, etc. Este mesmo corpus de Bowra, em The Truth of Poetry de Michael Hamburger (1996, pp. 81-109), figura nos capítulos em que o crítico americano procura sublinhar a clara preferência pelos temas do intimismo em detrimento da preocupação social.

Esta viragem ao intimismo significou muita vez a formulação, na poesia, de um sentimento de nostalgia por uma plenitude perdida. Seria, pois, o sentimento de "incertidumbre frente a los valores e ideas que fundaron a la modernidad" (2003, p.505)

${ }^{1}$ Mestrando em Literatura Portuguesa pela Universidade de São Paulo (USP) 
descrito por Octavio Paz. A argumentação de Paz interessa por ver no simbolismo "una traducción en la que el romanticismo se vuelve sobre sí mismo, se contempla y se traspassa, se interroga y se trasciende" (2003, p.391).

É neste grande quadro teórico que inserimos nosso percurso analítico: parte-se do detalhe de uma imagem recorrente, ao que se segue um excurso pelos temas do decadentismo-simbolismo ${ }^{2}$ para, então, concentrar-se mais detidamente em dois poemas.

I

Sobre a relação da modernidade com a tradição, anteriormente levantada, Nemésio, em prefácio para uma coleta de poemas, assim comenta:

como não foi só uma revolução de gosto, válida nos limites históricos, o Romantismo afectou e reviu todo o património poético ocidental, de Homero a Dante como de Dante a Shelley e - ainda hoje que tão longe dos românticos nos cremos - como de Shelley a Rilke. (1989, p.705)

Aproveitemos a lembrança de Shelley e o mito que lhe serviu de tema em Prometheus Unbound. Na mitologia grega (BRANDÃO, 1993, pp.166-167), Prometeu é tido como criador e protetor da humanidade. Tal zelo pelos homens fez com que enganasse, por duas vezes, a seu primo Zeus. A trapaça não passou impune: o senhor do Olimpo, como condenação, privou os homens do fogo sagrado, símbolo da inteligência, e acorrentou Prometeu a uma pilastra, onde uma águia consumia parte de seu fígado diariamente. O castigo seria perpétuo já que o órgão tem a capacidade de autoregeneração.

O herói seria a síntese do elã combativo dos românticos, livre de sentimentos vulgares. Superado o heroísmo titânico contido na figura prometéica, "Shelley es efectivamente el poeta de la intimidad dolorosamente conquistada" (DURAND 1993,

\footnotetext{
${ }^{2}$ Não se trata aqui de discutirmos o quão frágeis são as fronteiras impostas pela periodização da historiografia da literatura. A própria etiqueta "simbolista-decadentista" carrega posicionamentos antagônicos da crítica: Anna Balakian entende Simbolismo e Decadentismo de forma imbricada (2000, p.68), ao passo que José Carlos Seabra Pereira dedica toda a primeira parte de seu Decadentismo e Simbolismo na Poesia Portuguesa (1975, p.3-102) na tentativa de particularizar estas definições. Para este, o Simbolismo seria, grosso modo, uma superação das questões decadentistas. No entanto, o próprio autor admite que a produção finessecular muitas vezes se tratou de uma "poesia em que se estratificam, de forma variável - mas sempre desproporcionada - duas estéticas: a do Decadentismo predominante e a do Simbolismo deficientemente implantado" (1975, p.394). Desta sorte, "decadentista-simbolista", neste trabalho, refere-se aos temas e procedimentos estilísticos do fin-de-siècle tomados de forma conjuntiva, quer pela sua própria condição- como quer Balakian -, quer por sua existência, muitas vezes, estratificada - como aponta Seabra Pereira.
} 
p.259; itálico nosso). Este movimento antagônico confluirá no pessimismo decandentista-simbolista que, como lembra Fernando Guimarães, "é, ainda, uma das marcas que parece ter ficado do herói romântico submetido à tensão entre os valores da sua própria individualidade e a iminência da sua dissolução, enquanto indivíduo, no todo" (1990, p.10). Em outras palavras, a conquista romântica da intimidade tornar-se-á extremamente problemática nas últimas décadas do século XIX.

Em Nemésio, em quatro oportunidades tem-se a sugestão de uma imagem curiosamente próxima. Destaquemos as passagens ${ }^{3}$ : “E meu coração - descarne-o / Seu bico ardente como uma brasa", "Eu, ali, uma coisa imaginada / Que o eterno pica," e "Que uns pernaltas já tristes aproveitam, / Picam em meu coração / Como se fosse numa flor".

Nestes três excertos, observamos a imagem do homem, metonimicamente representado pelo coração, atacado por aves. Mutatis mutandis, estamos diante de um episódio do mito prometéico. É interessante notar que, se o herói romântico era o símbolo de liberdade - daí o Prometeu shelleyano ser unbound -, o mitologema aproveitado por Nemésio é o do suplício, o da condenação. O eu-poético, assim, acercase do "herói" decadente, misto de sofrimento e imobilismo: "E o bicho sempre em seu letargo / Como o avaro em seu tesouro! // Ponta fria da terra / Lá no mar penetrada / É saudade estendida;".

Esta "ponta fria da terra", que é saudade, caracteriza também este eu-lírico que se apresenta como aquele que arrefeceu. Percebem-se congregadas as idéias de inércia e de frialdade: "Nasci num astro que esfriou. / A escolta de anjos em que vim, perdi-a." e "Em céu e terra tudo é frio / Quanto ficou de outro festim". Este percurso ao gélido é exposto de forma patente no poema "Primavera embuçada", em que, após o retrato do ambiente primaveril, tudo parece inverter-se, em filiação ao topus do "mundo às avessas": "A primavera negou-se / E o poeta secou seus versos na tristeza".

Poeta e tristeza ladeiam-se na poesia nemesiana. O poema 24 de $E u$, comovido a Oeste, carregado de nostalgia, tão belamente expressa esta melancolia como destino do poeta: "Mas ainda há a tristeza a carregar / E as coisas que só pesam pelo aroma." Está

\footnotetext{
${ }^{3}$ Passamos a citar as Obras completas de Vitorino Nemésio na edição de 1989 da Imprensa Nacional Casa da Moeda. Os poemas citados ao longo deste estudo concentram-se, em sua totalidade, em três livros de sua lírica inicial: Bicho Harmonioso (1938), Eu, comovido a Oeste (1940) e Nem toda noite a vida (1952).
} 
dito também em "Repúdio" ("Não vejo menos nem mais / do que a tristeza que venho.") e, com letras capitais, em “A minha voz” (“Aí está: TRISTE. Se era a palavra, aí está.”).

Seguindo o tom de melancolia imanente, o imaginário temporal privilegia determinados momentos do ano (inverno e outono) e do dia (o crepúsculo e a noite): "Eu volto à mão do outono em meus papéis. / Penso e, indiscreto, o ar remove / Estas imagens cruéis / Que a vida comove." Tal preferência, obviamente, não é ocasional e guarda semelhança com o que assinala Mallarmé, em seu poema em prosa "Plainte d'automne":

j'ai aimé tout ce qui se résumait em ce mot: chute. Ainsi, dans l'année, ma saison favorite, ce sont les derniers jours alanguis de l'été, qui précèdent immédiatemment l'automne et, dans la journée, l'heure où je me promène est quand le soleil se repose avant de s'évanouir (2008, p.89)

La chute, a queda, reforça a noção de fatuidade, de evanescência das coisas e do próprio eu. Os momentos de sol revelam-se ilusórios ou, no dizer de Camilo Pessanha, "de falsas alegrias": "Manhã tão pura e breve / Que aquele botão de rosa nem resume / [...] / Oh! Uma manhã de menos! / O que isto significou!"

A fugacidade do tempo, em geral, é representada por imagens aquáticas dentro do topus do pantha rei heraclitiano. Prolifera, assim, a metáfora do "beber": "Quando eu morrer, a terra aberta / me beba de um trago" e "O dia bebeu-nos".

Não é a efemeridade, contudo, a única questão existencial com a qual o eu-lírico se defronta no exercício de sua consciência. Incluem-se, entre os temas, a impossibilidade de resposta aos grandes mistérios - o que implica na quase inutilidade do questionamento e, conseqüentemente, conduzem o sujeito ao silêncio - e a instransponível condição monádica, solitária do homem - e dela o decorrente sentimento de incompletude, de desterro, superável apenas com a experiência-limite da morte: "Silêncio é peso de Deus. / Levantar a voz começa / A pôr o homem sozinho" e "Agora sinto-me bem; / Os mortos, na verdade, são umas pessoas bem completas."

Nas palavras de Eduardo Lourenço, "Nemésio pertence até ao cerne a um mundo dividido, contraditório, insalvável, e, nessa medida, sem verdadeiro lugar para a poesia” (1974, p.146; itálico do autor). Não surpreende, portanto, que este Eu, posto diante do espelho, desdobre-se em imagens de esterilidade: "Quantas cadeiras como esta / Dão o fruto que eu sou! // O fruto seco / E, como os pêssegos, peludo, / Roído, cheio 
de peco, / Semente estéril de tudo." e “- Pobre e estéril jardim / Que seca tudo o que amanho."

A impotência humana deste Eu-poeta é a mesma de sua poesia, por isso o seu "duplo lírico", o bicho harmonioso, tão logo conclui sobre seu canto: "Não chego a soltar senão uma vaga nota, / E a noite faz muito bem em vergar uma gruta sem ecos / No meu buraco vil de bicho harmonioso." A noite identificada com a feliz metáfora da "gruta sem ecos" potencializa a improdutividade da poesia tanto na perspectiva do emissor - em toda sua infertilidade cônscia - como na do receptor - afortunadamente poupado do canto, já que este não ecoa, não repercute.

Os versos citados permitem ainda geografar e discutir o locus poético do eulírico. A casa é um dos ambientes insistentemente evocados (além do mar e do campo). Associar a toca deste "animal" ao céu noturno é, na verdade, negar a própria morada. Isto se repete no soneto "A Concha" ("Minha casa sou eu e os meus caprichos") e na bela quadra de abertura de Eu, comovido a Oeste: "Quem não tem casa sua / Faça da noite pedra / Ou talhe o seu coração, / Que já não dorme na rua". O sujeito está posto no mundo sem a possibilidade de abrigo, ainda que - e talvez exatamente por isso - as imagens domésticas sejam tão presentes. Trata-se, pois, de uma realidade manifesta pela negatividade ${ }^{5}$.

II

Este refúgio interdito e manifesto problematicamente na poesia nemesiana fecham o círculo no que concerne ao tratamento do intimismo romântico e decadentista e já nos permite delinear o ethos da persona poética. Analisamos, agora, o poema que segue:

Navio

Tenho a carne dorida

Do pousar de umas aves

Que não sei de onde são:

Só sei que gostam de vida

Picada em meu coração.

\footnotetext{
${ }^{4}$ Aludimos ao prefácio de Poesia (1935-1940), no qual o próprio autor tece uma auto-análise e vê no "bicho harmonioso" seu duplo lírico. (1989: 711)

${ }^{5}$ Voltamos à questão da negatividade ao analisarmos "O Pastor Morto".
} 
Quando vêm, vêm suaves;

Partindo, tão gordas vão!

Como eu gosto de estar

Aqui na minha janela,

A dar miolos às aves!

Ponho-me a olhar para o mar:

- Olha um navio sem rumo!

E, de vê-lo, dá-lho a vela,

Ou sejam meus cílios tristes:

A ave e a nave, em resumo,

Aqui, na minha janela.

A primeira estrofe repete a imagem do suplício prometéico: aves a assaltar o eulírico. Logo, é preciso averiguar a natureza simbólica destas “aves”, que são, a um só tempo, tormento e prazer ("carne dorida" e "como eu gosto..."). Alguns versos dão pistas neste sentido: “Ah, que o canário é o meu sangue talvez!" ou "Que milhafre criou minha carne em seu bico?" ou ainda "Sempre gostei de aves e de lágrimas. / Lágrimas, agora, não podia, / Mas podia os alciões / - E dei-lhes meus olhos para ovos".

As imagens aviárias estão ligadas à constituição do sujeito e, em última hipótese, metalinguisticamente à própria poesia ${ }^{6}$. A postura do $\mathrm{Eu}$, desta maneira, deixa sua forma passiva para assumir outra ambivalente: é ele o assaltado, mas também é ele a doar-se. São as aves a possibilidade de um utópico ovo, sinal de um tempo diverso, que aponta para o futuro ("E um ovo, /[...] /Que desse vida, penas, povo / Para as aragens e areais.") e para o passado (“Ah, o ovo que deixei, bicado e quente, / Vazio de mim, no mar").

As aves estão sob o signo de uma construção, que é alimentada pelo (próprio) Eu, mas que também o constitui - no mencionado duplo movimento ativo-passivo. Observemos duas passagens do poema "Minha voz": "Quando acabares o pão, pede mais, / Pois te darei a tua parte:" e "Vamos a ver se eu te crio, / A ti que me encheste de ser". Em "Navio", as duas estrofes, formalmente, plasmam as forças ("picada em meu coração" e "a dar miolos às aves") que competem e se equilibram no cerne de sua poética: o palco da coincidentia oppositorum. Para ecoar o anterior Eduardo Lourenço, Mircea Eliade, ao se questionar sobre o que revelam os mitos e símbolos religiosos que implicam a reunião dos contrários, afirma: “[revelam] antes de tudo, uma profunda

\footnotetext{
${ }^{6}$ O poema "Canção do Búzio Velho", por exemplo, traz a imagem do "cisne agoniado", um topus na simbologia do poeta, que, na modernidade, ganha força na poesia de Mallarmé. O "Minuete da impaciente", por sua vez, explora, inclusive, o potencial polissêmico de "penas".
} 
insatisfação do homem com a sua atual situação, com aquilo que se chama condição humana. O homem sente-se dilacerado e separado.” (1999, p.127)

Em Nemésio, poderíamos dizer que os opostos procuram se harmonizam ("num negrume que afinal é toda luz que nos fica" ou "O malmequer me quis bem"). Contudo, ao Eu que a todo o momento dá provas de sua aguda consciência qualquer tentativa de uma estável comunhão mostra-se frustrada. Aquilo que Paul de Man percebe nos fracassos mallarmeanos caberia aqui: "when he thought to have reduced the totality of being to a status that makes it fit to be expressed in language, he had been deceived by part of it that he did not reach" (2005, p.160). Qualquer demanda de fixação pela poesia acaba por afastar o Eu da realidade concreta: “Que eu já só choro por medida / De versos, e (o que é pior) / Digo que choro: aprendo a vida / Talvez um pouco de cor." e "Que esta vida cantada / Já nem sequer é vida".

Estes últimos versos, extraídos de "O abuso da Harmonia", estabelecem diálogo com "O Bicho Harmonioso" e tocam, portanto, no ofício poético. Adiante ele conclui "Seu eu não cantasse tanto / Vivia o dobro". O destino de poeta prende-o até o âmago, sem possibilidades evasivas, ao confronto das questões de uma existência carente de respostas em seus propósitos últimos. Se sua condição é a do ser destacado, o adjetivo aqui não assume o caráter daquele que se sobressai, mas sim daquele que está isolado, separado e, portanto, obrigado a conviver com a tensão de seu senso diferenciado manifesto em seu canto: "Quando desejo ser (bem sei que minto) / Só paciência e marcha, como os mais".

Para este sujeito tensionado, a janela é, por excelência, o lugar de observação ("Pobre janela aberta, / Minha medida, / A boca da minha casa"). Deste ponto eleito, o Eu enquadra o mundo, o que significa dizer que o olhar não incide livremente sobre o objeto, mas condicionado por um mediador (ou como dirá em "Uns Pinheiros: "Eu, na minha varanda de palavras"). A perspectiva do Eu não é unilateral, assim alternam-se momentos de observação dentro-fora. Georges Poulet, ao interpretar o poema "Les fênetres" de Mallarmé, comenta: "D'um cote de cette vitre, le poete; de l'autre son image magiquement transformée en elle d'un habitant de l'Azur : Je me mire et me vois ange... $\square$ "(1952 apud REBELO 2005, p.32). Na modernidade de Nemésio, não há alternativas mágicas, mas existe - e isto nos interessa - esta dinâmica possibilitada pela janela: olhar e ver-se, i.e., ser olhado. 
Logo, em "Navio", o achado poético aproxima o olhar ativo e seu produto pelo jogo paranomástico, vê-lo/vela. Mas, se há um princípio de organização (a poesia dar rumo ao $\mathrm{Eu}=$ "de vê-lo, dá-lho vela"), a condição do poeta e a consciência de seu estado (na metonímia dos "cílios tristes") desarticulam disforicamente a tentativa de síntese. Talvez por isso, "ave" está contido em "nave": se a poesia é potencialmente livre, não o é o poeta consciente: para o olhar a sua janela.

A nau como duplo do homem é retomada em outros poemas. Trata-se também da viagem, cujo itinerário é desconhecido e cumprido solitariamente (“Aqui - um por todos e todos por um, / Embora, na verdade, não haja mais que um,"). O tema foi muito caro aos simbolistas: está em Mallarmé ("Salut", "Brise Marine”) e, exemplo mais próximo, em Camilo Pessanha. $\mathrm{O}$ ambiente marinho sugere a imensidão, o absoluto e, por extensão, a completude da morte. Aqui, novamente, a imagem é de extração decadentista- simbolista. Os versos de António Nobre - "Quando eu morrer, hirto de mágoa, / Deitem-me ao Mar!"7 - ganham eco em Nemésio: "E vou, lavado em mar e enxuto em ossos, / Buscar a minha estrela aos céus de Oeste:" e "E levem-me - só horizonte - para o mar."

A aproximação quanto ao tema da morte possibilita dois desdobramentos. Se é verdade que há uma conotação de restabelecimento de completude existencial através da morte, ela nunca ocupará, na poesia de Nemésio, o lugar que tem na de Pessanha e Nobre, por exemplo. Como lembra Seabra Pereira, o tema da mors liberatrix para estes poetas estava ligado a certa abulia e ao "alheamento do corpo e da alma como única fonte de pacificação" (1975, p.344). Em Nemésio, os poemas sob este tema parecem mais imbuídos de um sentimento de "preparação para a morte", para evocarmos termos bandeirianos.

Outra consideração relevante diz respeito ao panteísmo contido nos versos. A figura do mar traz consigo a sugestão do ventre uterino, ou seja, a morte neste ambiente também é reintegração a uma instância pré-natal totalizante. Consideremos o poema "O pastor morto" de temática análoga:

O Pastor Morto

De madrugada a neve envidraçou-o.

Seus olhos rasos de um espanto podre,

As águias o mediram pelo vôo

\footnotetext{
${ }^{7}$ Do poema “António" (2009, p.61)
} 
E se encheu de silêncio como um odre.

Cheirado dos carneiros atrevidos,

Húmido fica já no fio lilás,

Aquilo sim, é que se chama paz,

Ali, à serra e à morte todo ouvidos!

Lá vêm as flores da neve à sua cara

E seu rubor perdido copiado

Pelo extenso corar das ervas gordas.

Atravessa, atravessa os rolos frios

Do tempo, o nevoeiro, e o passo às hordas,

Dourado e podre sob os astros frios.

Os dois quartetos põem em contraste o pastor estático no local de sua morte e a movimentação da natureza ao redor. O silêncio ganha estatuto outro na medida em que, tal como procede com imagens domésticas, presentifica-se ("encheu-se como um odre").

Olhemos a cena novamente: este homem morre na montanha onde provavelmente trabalha, morre em meio ao rebanho que agora o fareja. Para além da delicadeza e simplicidade, o quadro imprime um forte caráter de pertencimento àquela terra - tanto do ambiente que pertence ao homem, como do contrário, que parece mais verdadeiro, do homem que pertence ao ambiente.

Este é o prelúdio para os tercetos finais, nos quais o teor panteísta discutido é patente: as flores parecem absorver a cor do morto que empalidece; a neve, tornada flor, cai sobre sua face como se a natureza lhe provesse os trabalhos fúnebres; e a imagem final do nevoeiro, aludindo ao tempo, a assimilar completamente o homem.

O verso que sintetiza a sensação de paz (“Ali, à serra e à morte todo ouvidos!”), ao atribuir ação ao pastor morto, sinaliza esta outra possibilidade de perdurar a existência através da libertação da individualidade. A mesma dinâmica vida-em-morte identificada com o todo da natureza está posta em "Desabafo" ("Terei vestido e pão no mar e nos seus fundos / E nos peixes de cor as flâmulas de guerra; / Hei-de cravar o Sol no meu destino.”)

"O Pastor morto" ainda interessa pela sua estrutura; afinal, sua forma e metro são os tradicionais por excelência. No entanto, o tema, para tomarmos a invocação $\mathrm{d} \square$ Os Lusíadas, está mais para a "frauta ruda" do que para a "tuba canora" que os decassílabos sugerem. A antiguidade clássica tinha prescrições claras quanto aos estilos, 
a depender da natureza dos assuntos. A morte deste pastor anônimo cantada nas notas idílicas da "avena" é elevada não só pelo tratamento a que o poeta lhe dispensa mas também pela forma do soneto, o que revela um traço importante da lírica nemesiana, cujo olhar é extremamente sensível para a beleza das cenas simples ${ }^{8}$.

Se "Navio" é, como lemos, um poema de propensão intimista sobre a constituição do sujeito e sobre o alcance da linguagem neste processo, ele insere-se numa das mais altas discussões da modernidade. A dicção, no entanto, não se investe do modo grandioso que recomendava o decoro clássico. A própria escolha lexical denuncia isto: "aves gordas", "dar miolos" e "carne dorida" - o mesmo poderia ser dito de "O Pastor Morto": "neve à sua cara" e "ervas gordas".

Este pendor ao registro humilde revela uma sensibilidade que não hierarquiza temas, imagens e formas e vê até no mais singelo a potência do sublime. Parece ser esta a opção explicitada por Nemésio justamente no poema "Arte poética": "Nem o abstracto nem o concreto / São propriamente poesia. / Poesia é outra coisa. / Poesia e abstracto, não."

A chave de leitura não há de ser nem idealista, nem materialista, pois pressupõem a primazia deste ou daquele domínio. A poesia existe em uma autonomia possibilitada justamente por esta viragem da humildade. A lírica incial nemesiana não adere, com isto, nem a uma noção do concreto da tendência neo-realista da década de 40, tampouco à "imaginação psicológica" abstratizante da geração anterior presencista. A voz poética é modulada de forma livre, o que lhe permite criar um singular registro poético no Modernismo e aproveitar temas decadentistas sob rupturas e inversões da humildade.

Em outras palavras, se Óscar Lopes acerta em apontar "o jardim de temas da sua infância açoriana" (1989, p.1117), há de se considerar também, como procuramos demonstrar, que estes temas e imagens, reelaborados pela sensibilidade particular do poeta, têm notas decadentistas, o que imprime nuanças interessantes à produção de Nemésio.

\footnotetext{
${ }^{8}$ Tematicamente, está nos "versos dedicados a uma cabrinha que tive", em Eu, comovido a Oeste; quanto ao tratamento do tema, em "Canção do Búzio Velho", no qual a inversão humilde contrapõe a adjetivação do búzio ("velho", "ridículo", "malhado", "búzio de bicho comido", "relho", "desusado") ao valor daquilo que ele evoca e ao canto em si; e, na apresentação da persona poética, em "Desabafo", cujos versos "Não espero amor nem glória de ninguém: / Espero terra e cinza" condensam este sentimento de desprendimento e humildade.
} 


\section{BIBLIOGRAFIA}

NEMESIO, Vitorino. Obras Completas. Lisboa: IN/CM, 1989. vv. 1 e 2

BALAKIAN, ANNA. O Simbolismo. São Paulo: Perspectiva, 2000.

BERARDINELLI, Alfonso. Da poesia à prosa. SP: Cosac Naify, 2007.

BOWRA, C.M. The heritage of Symbolism. London: Macmillan \& Co, 1954.

BRANDÃO, Junito de Souza. Mitologia grega. Petrópolis: Vozes, 1993.

CALINESCU, Matei. Five faces of modernity. Durham: Duke University Press, 1999.

DORRA, Henri (org.). Symbolist Art Theories - a critical anthology. Los Angeles:

University of California Press, 1995.

DE MAN, Paul. "Double aspect of the Symbolism" in Romanticism and Contemporary

Criticism. Maryland: The Johns Hopkins University Press, 2005. pp. 147-163

DURAND, Gilbert. De la mitocritica al mitoanálisis. Barcelona: Anthropos, 1993.

ELIADE, Mircea. Mefistófeles e o Andrógino. São Paulo: Martins Fontes, 1999.

GUIMARÃES, Fernando. Simbolismo, Modernismo e Vanguardas. Lisboa: IN/CM, 2004.

. Poética do Simbolismo. Lisboa: IN/CM, 1990.

HAMBURGER, Michael. The truth of Poetry. London: Anvil Press Poetry, 1996

PARIS-MONTECH, Christine. L'imaginaire de Camilo Pessanha. Paris: Centre Culturel Calouste Gulbenkian, 1997.

LOPES, Óscar. Entre Fialho e Nemésio. Lisboa: IN/CM, 19871

LOURENÇO, Eduardo. "Vitorino Nemésio ou da livre navegação (no mar poético de Deus)” in VV.AA. Críticas sobre Vitorino Nemésio. Lisboa: Livraria Bertrand, 1974.

MALLARMÉ, Stéphane. Collected Poems. Los Angeles: UC. Press, 2008.

NOBRE, António. Só - seguido de Despedidas. São Paulo: Ateliê Editorial, 2009.

PAZ, Octavio. La casa de la presencia. Poesia e historia. Obras Completas. Edición

Del autor. Vol. 1. México: FCE. 2003

PESSANHA, Camilo. Clepsydra. Lisboa: Relógio D $\square$ Àgua, 1995.

PEYRE, Henri. A literatura simbolista. São Paulo: Cultrix, 1983

PEREIRA, José Carlos Seabra. Decadentismo e Simbolismo na Poesia Portuguesa. CER., Coimbra, 1975. 
REBELO, Diva Valente. O fascínio das janelas em Mallarmé. SP: USP, 2005 186p. Tese - Programa de Pós-graduação em Literatura Francesa do Departamento de Letras Modernas da FFLCH-USP, 2005.

RILKE, Rainer Maria. Poemas. São Paulo: Companhia das Letras, 1993.

SARAIVA, Antonio José e LOPES, Óscar. História da Literatura Portuguesa. Porto: Porto Ed., 1989.

SHELLEY, Percy Bysshe. Prometheus unbound. London: J.M. Dent \& Sons, 1939.

TROUSSON, Raymond. "Prometeu” in Dicionário de Mitos Literários. Rio de Janeiro: José Olympio, 1997. pp. 784-793 